\title{
FIBER-REINFORCED FIXED PARTIAL DENTURES: A PRELIMINARY RETROSPECTIVE CLINICAL STUDY
}

\author{
PRÓTESES PARCIAIS FIXAS REFORÇADAS POR FIBRAS: \\ UM ESTUDO CLÍNICO RETROSPECTIVO PRELIMINAR
}

Edno Moacir PIOVESAN ${ }^{1}$, Flávio Fernando DEMARCO² ${ }^{2}$ Evandro PIVA²

1- Private Practice, Pelotas/RS, Brazil.

2- Associate professor, Department of Operative Dentistry, Dental School, Federal University of Pelotas, Pelotas/RS, Brazil.

Corresponding address: Flávio Fernando Demarco, Department of Operative Dentistry, Dental School, Federal University of Pelotas, Rua Gonçalves Chaves, 457 - Centro, Pelotas-RS, Brazil. Cep.: 96015-560. Phone Number: 55-53 2723823, Fax Number: 55-53 2255581, e-mail: fdemarco@ufpel.edu.br

Received: March 31, 2005 - Modification: August 08, 2005 - Accepted: January 19, 2006

\begin{abstract}
$T_{\text {h }}$ Le aim of this study was to evaluate the clinical performance (retention rate) of fiber-reinforced composite fixed partial dentures (FPDs). Polyethylene fiber $\left(\right.$ Ribbond $^{\circledR}$ ) was used combined with restorative composite during FPDs fabrication. FPDs were placed in thirteen patients in a private clinic. Nineteen FPDs were evaluated. The prosthetic space was filled with only one pontic using extracted teeth (2 cases), acrylic resin teeth (11 cases), or with composite resin (6 cases), combined with Polyethylene fiber. The clinical criterion used was based on retention rate of FPDs. If FPDs were in function in the mouth at the time of examination without previous repair they were classified as Complete Survival (CS) restorations. A classification of Survival with Rebonding (SR) was assigned in the event of an adhesive failure, but after rebonding the FPD still remained under evaluation. Treatment was classified as a Failure (F) if the FPD restoration was lost. The time of evaluation was 41.15 months ( \pm 15.13$)$. The FPDs evaluated were retained (CS=94.75\%), and no failure was found except for in one situation which required rebonding ( $\mathrm{SR}=5.25 \%$ ). According to the survival estimation method of Kaplan-Meyer the mean survival time was 42.3 months. At the time of evaluation investigated, polyethylene-reinforced FPDs showed a favorable retention rate in preliminary data. Uniterms: Polyethylene, clinical trial; Composite resins; Reinforced dental composites.
\end{abstract}

\section{RESUMO}

objetivo deste estudo foi avaliar a performance clínica (percentagem de retenção) de próteses parciais fixas reforçadas por fibras. Fibras de polietileno (Ribbond ${ }^{\circledR}$ ) foram usadas em combinação com resina composta durante a confecção das próteses. Os tratamentos foram realizadas em 13 pacientes, em uma clínica privada., sendo que 19 próteses foram reavaliadas. O espaço protético era preenchido com um pôntico usando o próprio dente extraído (2 casos), dentes de acrílico (11 casos) ou confeccionados com resina composta (6 casos), em todas as situações eram empregadas fibras de polietileno. Os critérios clínicos usados foram baseados na percentagem de retenção das próteses parciais fixas. As próteses que estavam em função no momento da avaliação, sem nunca necessitar de qualquer reparo prévio, foram classificadas como sobrevivência completa (SC). A classificação de sobrevivência com nova colagem (SR) foi utilizada para os casos de falha adesiva, com posterior cimentação da peça, a qual permanecia em função. $\mathrm{O}$ tratamento era classificado como falha (F) quando a restauração era perdida. O tempo médio de avaliação foi de 41,15 meses $( \pm 15,13)$. Nenhum caso de falha foi detectado, em apenas um caso houve falha adesiva com posterior colagem da peça (SR=5,25\%) e em $94.75 \%$ dos casos as próteses permaneciam em função.. De acordo com o método de sobrevida de Kaplan-Meyer o tempo médio de sobrevida foi de 42,3 meses. As próteses parciais fixas reforçadas por fibras mostraram uma percentagem de retenção favorável neste estudo preliminar.

Unitermos: Polietileno, avaliação clínica; Resinas compostas; Resinas compostas reforçadas. 


\section{INTRODUCTION}

The replacement of a single tooth lost due to dental caries or trauma is a challenge for the clinician. Several restorative options have been proposed in such clinical situations: implants, fixed metal ceramic or ceramic prostheses and resin bonded fixed partial dentures (FPDs). However, economic factors, occlusal disturbances, lack of adequate bone support or excessive removal of healthy dental structure are some of the limiting factors in the indication of some restorative alternatives ${ }^{2}$.

The evolution of adhesive dentistry has significantly modified the concepts of traditional dentistry toward the minimal intervention approach. The FPDs were first proposed in the 70's as an alternative to traditional prosthesis. A pontic was bonded to the neighbor teeth using acid etching and composite resin, making such treatment attractive because of the minimum removal of dental structure ${ }^{20}$. These first treatments were called direct FPDs. The lost teeth could be replaced using acrylic resin teeth, extracted teeth or composite resin. Based on the limitations of this technique and in the high incidence of failures, FPDs with a metallic framework (indirect FPDs) were introduced ${ }^{20}$. Resin cement application has enhanced the clinical success of these treatments ${ }^{11}$. Retention rates of $90 \%$ were found after 5 years and $70 \%$ after 10 years ${ }^{4}$. Even with the perspective of failure this treatment provides high satisfaction for the patients and the prosthesis could be rebonded after displacement caused by adhesive failure ${ }^{5}$.

Clinical trials have determined some potential risk factors for posterior FPDs: the location (mandible, relative risk (rr) = 2.2 ), time of placement (more than 2 years, $r r=2$ ), and large prosthetic spaces in mandible $(\mathrm{rr}=3.1)^{5}$. When the fixed partial dentures were well retained, the survival rate after 10 years was 95\%, but without appropriate retention the failure risk was increased 3.7 times $^{6}$.

The increasing concern about esthetics has decreased the application of restorations with metallic framework. One esthetic alternative to overcome this limitation is the placement of all-ceramic FPDs or performed with fiberreinforced composites. Vallitu and Sevelius ${ }^{21}$ observed high survival rate (93\%) after 24 months using resin-bonded fiberreinforced FDPs. After 37 months, 95\% retention rate was found in FDPs performed with a high-volume fibers framework ${ }^{19}$.

Altieri ${ }^{1}$ evaluated 14 fiber-reinforced FPDs and observed a low rate of success (50\%) after 1 year. However, the authors used glass fiber-reinforced polycarbonate and the failures were not attributed to the transverse fracture of the partial denture. Culy and Tyas ${ }^{7}$ followed 27 FPDs for 10 months and verified that 26 were in place. Using unidirectional glass fibers to reinforce FPDs, Valittu and Sevelius ${ }^{21}$ evaluated 31 specimens and found a success rate of $93 \%$ at 24 months.

In a 37-month follow-up of 39 FPDs made with a framework of pre-impregnated, unidirectional fiberreinforced composite, Freilich et al. ${ }^{14}$ observed a survival rate of $95 \%$. These authors stated that short-span polymer FPDs made with particulate composite and unidirectional glass FRC could be used in certain clinical situations in which a metal framework is not desired.

Since their introduction ${ }^{16}$, polyethylene fibers have been indicated for a series of clinical situations: splints, pin and core build-up, orthodontic retainers, reinforcement of composite restorations and others ${ }^{13}$. Several reports in the literature have reported the application of polyethylene fibers for FPDs fabrication, using extracted teeth ${ }^{2}$ or resin materials $s^{3,13,17}$. Literature lacks evidence about the clinical performance of this type of treatment. The purpose of this preliminary retrospective study was to evaluate the clinical success (retention rate) of polyethylene fiber-reinforced FPDs.

\section{MATERIALS AND METHODS}

\section{Patient selection}

The FPDs evaluated in this study were performed in a private dental clinic by an experienced operator. To be included in the study, patients should have a prosthetic space corresponding to a single tooth and no more than two fixed partial dentures could be placed in each patient. Patients with larger prosthetic spaces $(>15 \mathrm{~mm})$, parafunctional habits or extensive fixed or removable prostheses were excluded from the study. Polyethylene fiberreinforced FPDs (Ribbond, Ribbond Inc, Seattle, WA, USA) were placed from 1996 to 2001. The objective and the procedures to be performed in this study were approved by the Ethics Committee (Medical School, Federal University of Pelotas). Also, the patients were informed about the objective of the study and gave a written consent to participate in the research.

\section{Fabrication of the FPDs}

The FPDs were made in three stages: two clinical sessions and one laboratory step.

First clinical session: teeth were prepared using diamond burs (\#4138, \#3131) in high speed under air-water cooling. Burs were replaced after four preparations to ensure high cutting efficiency. In the occlusal surface, there was tooth reduction to allow placement of at least two polyethylene fiber strips. Class II (posterior region) and Class III (anterior region) cavities were prepared in the supporting teeth. A polyvinylsiloxane impression (Express, 3M ESPE, St Paul, MN, USA) was taken. The cavities were filled with provisional composite restorations (Z100, 3M ESPE, St Paul, MN,USA), cemented with calcium hydroxide cement (Hydro C, Caulk/Dentsply, Petrópolis, RJ, Brazil). A model was then prepared (Velmix, Kerr Corporation, Orange, CA, USA).

Laboratory step: The FPDs were prepared in the laboratory. The stone model was isolated using water-based gel (KY, Johnson \& Johnson, São José dos Campos, SP, Brazil). When the FPDs were built up with composite resin, a first layer of composite was placed in the pulp and axial walls and a first strip ( $3.5 \mathrm{~mm}$ thick) of adhesive-impregnated polyethylene fibers (Ribbondâ, Ribbond Inc, Seattle, WA, USA) was applied over it. Composite was light cured for 40 
seconds on each supporting tooth and at the pontic region. More composite layer was applied and a second polyethylene strip was placed. Additional composite was incrementally applied with Teflon spatulas to sculp, adapt and contour FPDs. Filtek Z250 (3M ESPE, St Paul, MN, USA), Renamel (Cosmedent, Chicago, IL, USA) and Vitalescence Incisal (Ultradent, South Jordan, UT, USA) composites were used in a stratified technique. FPDs were finished using 30blade burs (KG Sorensen, São Paulo, SP, Brazil) and polished using Sof-Lex XT Pop On (3M ESPE, St Paul, MN, USA) and Enhance (Caulk/Dentsply, Petrópolis, RJ, Brazil) with Enamelize polishing pastes (Cosmedent, Chicago, IL, USA). The internal surface of the FPDs was sandblasted with aluminum oxide $(50 \mu \mathrm{m})$. When acrylic teeth were used, there was a modification of the technique. Acrylic teeth (Ivoclar Vivadent, Schaan, Liechtenstein) were perforated in mesiodistal direction using a round diamond bur. After sandblasting, the acrylic tooth was wettened with acrylic monomer. One polyethylene strip impregnated in adhesive was introduced in the tunnel, composite resin was packed around the strip in the tunnel region and light cured for one minute. The lateral projections of the polyethylene fiber were covered by composite resin in the proximal cavities of the adjacent teeth. Finishing and polishing procedures were similar to the first group. Extracted teeth used belonged to the own patients. These teeth had the roots and the pulp tissue removed and were autoclaved $\left(120^{\circ} \mathrm{C}\right.$ for 15 minutes). After that, teeth were stored in saline solution with sodium azide (antibacterial agent) in a freezer $\left(4^{\circ} \mathrm{C}\right)$. The procedures for extracted teeth were similar to those performed for acrylic teeth, except for moistening with acrylic monomer.

Second clinical session: after removal of the provisional restoration, the FPD was cemented. All procedures were performed under rubber dam isolation. A total etch technique adhesive system (Single Bond, 3M ESPE, St Paul, MN, USA) and resin cement (Enforce, Caulk/Dentsply, Petrópolis, RJ, Brazil) were used. The materials were applied according to manufacturers' indications. A Demetron Optilux 400 (Kerr Co, Orange, CA, USA) light curing unit with $=600 \mathrm{~mW} / \mathrm{cm}^{2}$ of radiation was used for light curing. The occlusion was checked to avoid excessive loading or premature contacts.

Seven patients were females and six were males. Nine patients were between 26 to 45 years old and four were older than 45. Four FPDs were located at the incisors incisive region, ten at premolar and five at molar region. Eight fixed partial dentures were placed in the maxilla and eleven in the mandible. The description of subjects and FPDs is listed in Table 2.
The mean age at treatment was 41.1 months ( $\mathrm{SD}= \pm 15.13)$, with the minimum age 12 months and the maximum 57 months. In eleven cases the pontics were made with acrylic resin teeth, six pontics were performed using composite resin and in two cases extracted teeth were used. Extracted teeth were employed when they were available and were noncarious. The first fixed partial dentures were performed with acrylic teeth and the more recently placed were performed with composite resin.

\section{Clinical Evaluation}

Patients that had fiber-reinforced FPDs placed between 1996 and 2001 were recalled. These patients were regular patients of the dental office and were followed-up twice a year. Two experienced examiners performed the clinical evaluation in the same private clinic. Treatment success was based on criteria presented in Table 1. Radiographic examination was performed to detect the presence of secondary caries. Periodontal probing was made to evaluate the presence of bleeding and periodontal pockets.

The Kaplan-Meier survival method was used with SigmaStat 3.01 statistical software (SPSS Inc, Chicago, IL, USA).

\section{RESULTS}

Table 3 shows the status of FPDs. Eighteen FDPs (94.75\%) were classified as Complete Survival (CS), while one (5.25\%) was classified as Survival with Rebonding (SR) (Figure 1). No case of failure (F) was detected. The mean survival rate (complete survival) was 42.3 months (Standard Error $=3.44)$.

In the case classified as Survival with Rebonding, the FPD adhesively failed after 10 months during chewing and it was immediately rebounded, remaining in place until the final evaluation.

All patients presented healthy periodontal tissues and no case of secondary caries was found. Due to the small sample size, it was not possible to associate the success rates with other variables.

\section{DISCUSSION}

The main limitation of the present study was the small sample size, which does not allow investigation between retention rate and any other potential variable. Also, FPDs

TABLE 1- Criteria used to define the clinical condition of the resin-bonded fixed-partial dentures (modified from Creugers et al. $\left.{ }^{5}, 1998\right)$

Criteria

Complete Survival

Survival with rebonding

Failure

\section{Condition}

FDP in place, without any failure

Adhesive failure of the FDP, which was rebonded and remained in place Loss of the FDP without chance of rebonding 
were placed in different locations and they were performed with different materials. In addition, there is no control group to compare the clinical retention with that observed in the

TABLE 2- Description of the variables for each patient

\begin{tabular}{|c|c|c|}
\hline Variable & $\mathbf{n}$ & Frequency \\
\hline \multicolumn{3}{|c|}{ Gender of the patient } \\
\hline Male & 7 & $53.8 \%$ \\
\hline Female & 6 & $46.2 \%$ \\
\hline Total & 13 & $100 \%$ \\
\hline \multicolumn{3}{|l|}{ Age } \\
\hline 18-25 years & 2 & $15.4 \%$ \\
\hline $26-45$ years & 6 & $46.2 \%$ \\
\hline$>46$ years & 5 & $38.4 \%$ \\
\hline Total & 13 & $100 \%$ \\
\hline \multicolumn{3}{|l|}{ Location } \\
\hline Mandible & 11 & $57.9 \%$ \\
\hline Maxilla & 8 & $42.1 \%$ \\
\hline Total & 19 & $100 \%$ \\
\hline Anterior & 4 & $21 \%$ \\
\hline Posterior & 15 & $79 \%$ \\
\hline Total & 19 & $100 \%$ \\
\hline \multicolumn{3}{|l|}{ Material of Pontics } \\
\hline Composite Resin & 6 & $31.6 \%$ \\
\hline Acrylic Resin & 11 & $57.9 \%$ \\
\hline Natural Tooth & 2 & $10.5 \%$ \\
\hline Total & 19 & $100 \%$ \\
\hline
\end{tabular}

TABLE 3- Clinical situation of the evaluated FDPs

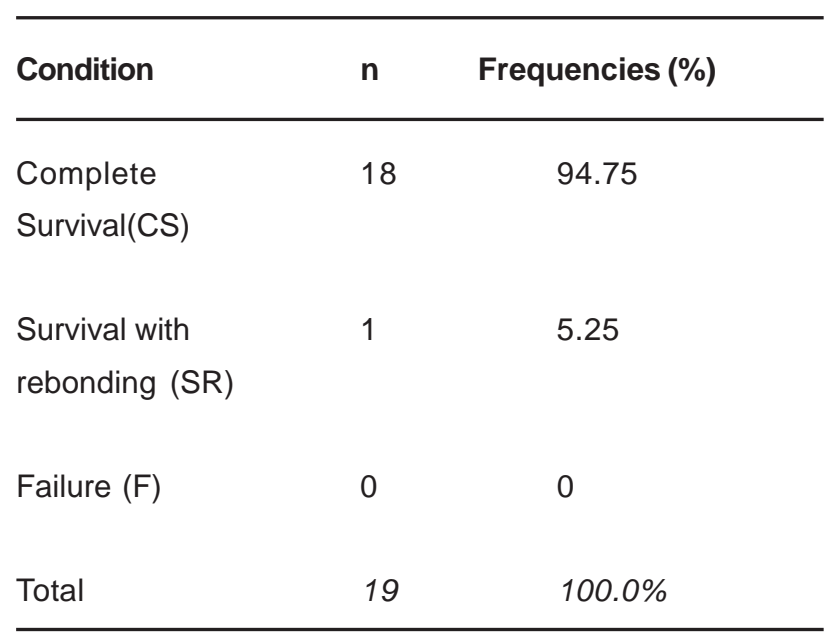

fiber-reinforced group. Nevertheless, the few clinical evaluation studies of fiber-reinforced FPDs were based on similar sample sizes as that reported in this study $y^{1,7,21}$ and they have also no control group.

Survival with replacement was included in the success category, because it is possible to rebond the resin-bonded FPD in case of adhesive failure ${ }^{2,5,6}$. In the present study, a favorable retention rate was observed after approximately three years. In addition, such retention rate is comparable to that observed with metallic FPDs at similar evaluation periods $^{4,5}$. In a meta-analytic study of 1,598 resin bonded metallic FPDs, Creugers and Van't Hof ${ }^{6}$ observed 84\% of clinical success after 3 years.

Some reasons could be pointed out to explain the favorable results observed in this study. All FPDs were performed by only one experienced operator and the operator experience has been considered a significant factor to influence the success rate ${ }^{8}$. Also, the cavity preparation was carefully made to allow proper space for fiber inclusion. A well-designed preparation is another significant factor on resin-bonded FPD retention ${ }^{8}$.

Another aspect is the potential reinforcement provided for polyethylene fibers ${ }^{16}$. The adhesion between the fiber and the composite could increase the resistance and the hardness of the material allowing deflection without fracture $^{18}$

In opposite, in vitro studies have failed to prove the enhanced mechanical properties of fiber-reinforced resin materials $^{9,19}$. However, problems with test designs could mask the importance of fiber reinforcement ${ }^{10,19}$. In another in vitro study evaluating the flexural resistance, when the fiber-reinforced composite samples had broken the polyethylene strip remained connected, without disruption ${ }^{19}$. Such finding could show the malleability of the material, which could be important in stressing clinical situations, like in a FPD.

The prosthetic space in resin-bonded FPDs is a significant factor to determine the treatment success. The distance should not be larger than $15 \mathrm{~mm}$, because the FPD would suffer a higher deflection and could fail ${ }^{5}$. A large

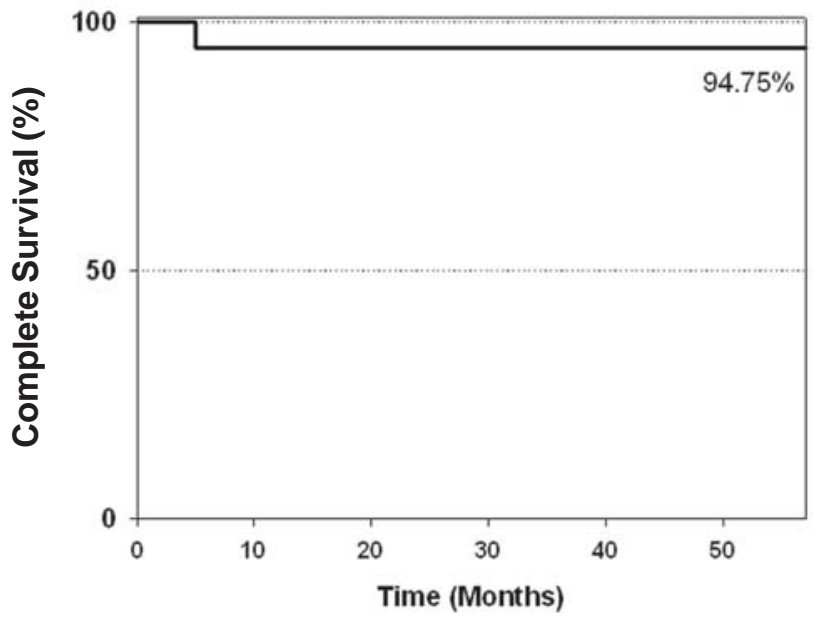

FIGURE 1- The overall complete survival curve (KaplanMeier) of the FPD illustrated a $94.75 \%$ survival rate 
prosthetic space in the mandible might increase the failure rate in 3 times $^{5}$. In the present study, no case had a prosthetic space larger than $15 \mathrm{~mm}$.

The use of additional polyethylene strips in the fabrication of the FPD and micro etching of the internal interface with aluminum oxide could also increase the resistance and mechanical adhesion with the composite resin, respectively ${ }^{12}$. In this study, the pontics were made in three forms: with natural extracted teeth, with acrylic resin teeth and using composite resin. When acrylic resin teeth were used, the polyethylene fiber was moistened using the acrylic monomer to increase bonding and resistance to fracture ${ }^{15}$. The use of natural extracted teeth is an alternative to be employed with good esthetic and functional results ${ }^{2}$. The limitation of this technique is the availability of intact natural teeth. In six cases the lost teeth were replaced using composite resin pontics, which also offers good esthetic results, through the ideal stratification of the natural colors of the tooth, combining different resin shades and viscosities ${ }^{12}$.

Nowadays, laboratory-processed fiber-reinforced resins for FPDs are available for clinicians, enhancing the flexural resistance of restorations ${ }^{14}$. However, these FDPs are more expensive than using direct composite.

The kind of treatment provided in this study has been considered long term provisional treatment. The results of this preliminary retrospective preliminary study suggest that polyethylene fiber-reinforced composite FPDs could be a functional and esthetic alternative to replace a lost tooth. However, long term longitudinal studies with higher number of FPDs evaluated should be conducted to confirm the preliminary findings reported in this study.

\section{REFERENCES}

1- Altieri JV, Burstone CJ, Goldberg AJ, Patel AP. Longitudinal clinical evaluation of fiber-reinforced composite fixed partial dentures: a pilot study. J Prosthet Dent. 1994;71:16-22.

2- Belli S, Ozer F. A simple method for single anterior tooth replacement. J Adhes Dent. 2000;2:67-70.

3- Belvedere PC. Single-sitting, fiber-reinforced fixed bridges for the missing lateral or central incisors in adolescent patients. Dent Clin North Am. 1998;42:665-82, ix.

4- Corrente G, Vergnano L, Re S, Cardaropoli D, Abundo R. Resinbonded fixed partial dentures and splints in periodontally compromised patients: a 10-year follow-up. Int J Periodontics Restorative Dent. 2000;20:628-36.

5- Creugers NH, De Kanter RJ, Verzijden CW, Van’t Hof MA. Risk factors and multiple failures in posterior resin-bonded bridges in a 5year multi-practice clinical trial. J Dent. 1998;26:397-402.

6- Creugers NH, Van 't Hof MA. An analysis of clinical studies on resin-bonded bridges. J Dent Res. 1991;70:146-9.

7- Culy G, Tyas MJ. Direct resin-bonded, fibre-reinforced anterior bridges: a clinical report. Aust Dent J. 1998;43:1-4.
8- Djemal S, Setchell D, King P, Wickens J. Long-term survival characteristics of 832 resin-retained bridges and splints provided in a post-graduate teaching hospital between 1978 and 1993. J Oral Rehabil. 1999;26:302-20.

9- Ellakwa A, Shortall A, Shehata M, Marquis P. Influence of veneering composite composition on the efficacy of fiber-reinforced restorations (FRR). Oper Dent. 2001;26:467-75.

10- Ellakwa AE, Shortall AC, Marquis PM. Influence of Different Techniques of Laboratory Construction on the Fracture Resistance of Fiber-Reinforced Composite (FRC) Bridges. J Contemp Dent Pract. 2004;5:1-13.

11- el-Mowafy O, Rubo MH. Resin-bonded fixed partial dentures-a literature review with presentation of a novel approach. Int $\mathrm{J}$ Prosthodont . 2000;13:460-7.

12- Fahl N, Jr. Restoration of the maxillary arch utilizing a composite resin buildup and a fiber framework. Pract Periodontics Aesthet Dent. 1998;10:363-7.

13- Ferreira ZA, de Carvalho EK, Mitsudo RS, Bergamo PM. Bondable reinforcement ribbon: clinical applications. Quintessence Int. 2000;31:547-52.

14- Freilich MA, Meiers JC, Duncan JP, Eckrote KA, Goldberg AJ. Clinical evaluation of fiber-reinforced fixed bridges. J Am Dent Assoc. 2002;133:1524-34; quiz 40-1.

15- Hannon SM, Breault LG, Kim AC. The immediate provisional restoration: a review of clinical techniques. Quintessence Int. 1998;29:163-9.

16- Kau K, Rudo DN. A technique for fabricating a reinforced composite splint. Trends Tech Contemp Dent Lab. 1992;9:31-3.

17- Miller TE, Margalit S, Creamer TJ. Emergency direct/indirect polyethylene-ribbon-reinforced composite resin, fixed partial denture: a case report. Compend Contin Educ Dent. 1996;17:182-4, 6-8, 90.

18- Nash RW. Reinforced composite resin: a restorative alternative. Compendium. 1994;15:554,7-60.

19- Pereira CL, Demarco FF, Cenci MS, Osinaga PW, Piovesan EM. Flexural strength of composites: influences of polyethylene fiber reinforcement and type of composite. Clin Oral Investig. 2003;7:1169.

20- Saunders WP. Resin bonded bridgework: a review. J Dent. 1989;17:255-65.

21- Vallittu PK, Sevelius C. Resin-bonded, glass fiber-reinforced composite fixed partial dentures: a clinical study. J Prosthet Dent. 2000;84:413-8. 